\title{
NOTE ON THE OCCURRENCE OF SALINE FRONTS IN THE ILHA GRANDE (RJ) REGION
}

LUIZ BRUNNER DE MIRANDA, YOSHIMINE IKEDA, BELMIRO MENDES DE CASTRO FILHO* \& NUNO PEREIRA FILHO*

Instituto Oceanográfico da Universidade de São Paulo

\section{SYNOPSIS}

Continuous records of temperature and salinity were obtained on the surface waters as function of the horizontal distances around Ilha Grande region, on June 21, 1975; an outflow of less saline $(\mathrm{S} \sim 33.10 \% / \mathrm{o})$ and slightly warmer water was detected throughout the region between Ponta de Castelhanos and Ponta Grossa da Marambáia and a visible manifestation of a saline front was observed in the interaction of this outflow with the coastal and more saline water $(\mathrm{S} \sim 35.4$ to $35.6 \%$ \% $)$. The recorded salinity values in the east region of Ilha Grande, suggest that the source of less saline water is the runoff in the Baía de Sepetiba.

\section{NTRODUCTION}

Small scale structure and thermal and saline variations across sharp discontinuities on the sea surface are not easily perceptible through discrete measurements. The observation and analysis of these and other phenomena is possible nowadays due to the development of equipment for continuous recording of phýsical and chemical properties of the sea water.

* Grants were awarded to the authors by Fundação de Amparo à Pesquisa do Estado de São Paulo (FAPESP). 
This paper presents the continuous measurements of thermal and saline structures on the surface water in the region of I1ha Grande and Baía de Sepetiba (Fig. 1). This region was studied mainly under the biological aspect by Tommasi et al. $(1972 a, b)$. A phenomenon similar to an occurrence of the type in the open sea, named "coastal saline front" by Amos et al. (1972) was observed. This visible front was detected across the southern entrance of the Baía de Sepetiba and its thermal and saline characteristics, as well as the structure of the inner and coastal neighboring water, were sampled during a period of twelve hours from 08:00 a.m. to 20:30 p.m. local time, in order to investigate its probable origin.

Visible oceanic fronts characterized by sharp surface discontinuities of temperature and/or salinity are a phenomen which has often been described in the oceanographic literature, as Cromwell \& Reid pointed out (1956), because of its biological and physical interest.

Laevastu (1973) reported the measurement and recording of surface air as well as the sea surface properties along repeated tracks of the Californian coast, which were established in order to study the formation of the coastal stratus and fog.

On studying turbulent convergent tidal fronts in the English Channel Pingree et al. (1974) found a high concentration of certain planktonic animals. In that paper, temperature, salinity, current measurements and direct visual observations have been used to describe the nature of the front and some dynamical considerations are made based on a two layer model.

\section{INSTRUMENTS AND METHODS}

The R/V "Prof. W. Besnard" which served as a working platform is equipped with a thermosalinograph, model 6600T (Bissett Berman), for simultaneous records of temperature $\left({ }^{\circ} \mathrm{C}\right)$ and salinity $(\%)$ on the near surface water, with an accuracy of $\pm 0.1^{\circ} \mathrm{C}$ and $\pm 0.03 \%$. Details on the equipment, installation and location of the remote sensors for temperature (thermistors) and inductive salinity measurements were described by Ikeda (1971) . 
This analogic record is controlled and corrected by discrete measurements of temperature and salinity, with reversing thermometers and a portable inductive salinometer, Beckman, model RS7-C. This procedure demonstrated that the analogic temperature measurements are systematically higher than the thermometric values, ranging from +0.56 to $+0.63^{\circ} \mathrm{C}$, the mean correction of $-0.6^{\circ} \mathrm{C}$ having been applied to the continuous temperature measurements. The comparison between the recorded salinity values and the inductive measurements on board showed that the deviations ranged from +0.07 to $-0.04 \%$. Since the mean value of this variation is smaller than the accuracy of the thermosalinograph $( \pm 0.03 \%$, no correction was applied to the analogic records of this property of the sea water.

The ship position was established by radar almost every 10 minutes (indicated by closed circles in Figure 1).

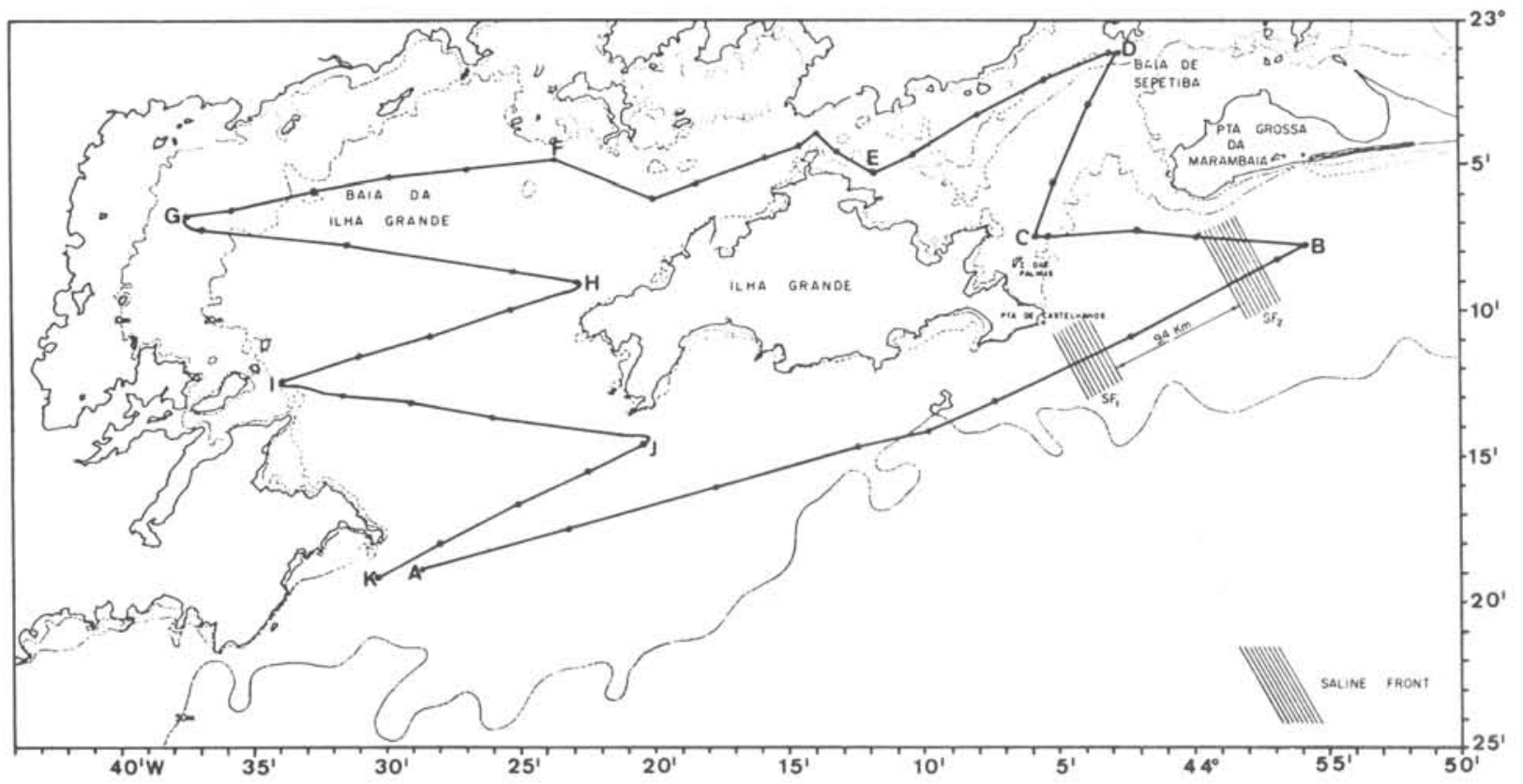

Fig. 1 - Tracks of continuous measurements of temperature and salinity around Ilha Grande and the position of the visible saline front on June 21, 1975 .

\section{SURFACE TEMPERATURE AND SALINITY STRUCTRURE AROUND ILHA GRANDE}

The simultaneous recording of temperature and salinity discussed in this paper had its initial position and time at Lat. $23^{\circ} 18,9^{\prime} \mathrm{S}$, Long. $44^{\circ} 28,7^{\prime} \mathrm{W}$ and 08:00 a.m., respectively. 
The first section $(A B)$ was sampled from 08:00 to 11:05 a.m. (Fig. 1). The thermal and saline structure along this section showed minor fluctuations (Fig. 2), up to the position reached at 10:20 a.m., SE of the Ponta de Caste1hanos, where a visible saline front was found $\left(S F_{1}\right)$. Across this front, the salinity structure presented a sharp decrease from $35.14 \%$ to $33.24 \%$ $(\Delta S=2.20 \%$ oo $)$. The strongest salinity gradient occurred in approximately 7 minutes corresponding to a space scale of about $2.5 \mathrm{~km}$ and a salinity gradient of $\sim 0.09 \% / \mathrm{hm}$. The temperature structure associated with this saline front showed a slight increase from $20.6^{\circ} \mathrm{C}$ to $20.9^{\circ} \mathrm{C}\left(\Delta \mathrm{T}=0.3^{\circ} \mathrm{C}\right)$.

The horizontal extent of the less saline water had a breadth of about $9.4 \mathrm{~km}$ and the boundary $S F_{2}$ between the low and high salinity water was located SE of Ponta Grossa da Marambáia (Fig. 1). Inside this boundary salinity increased from $33.00 \%$ to $35.56 \%(\Delta S=2.56 \%$ in a space scale of $1.6 \mathrm{~km}$, which corresponded to a salinity gradient strongest than that in the opposite boundary $(0.16 \% / \mathrm{hm})$. In this boundary the temperature decreased from $20.8^{\circ} \mathrm{C}$ to $20.4^{\circ} \mathrm{C}\left(\Delta \mathrm{T}=0.4^{\circ} \mathrm{C}\right)$.

The thermal and saline structure in the eastern region of Ilha Grande along the track $B D C E$ is shown in Figure 3. Twenty minutes after crossing of the boundary $S F_{2}$ when the ship course changed to west (Fig. 1, Point B), heading to the inner region of the Bay, the portion of the boundary closest to the Ponta Grossa da Marambäia was observed again. In this direction through the $S F_{2}$ boundary, it was observed that salinity dropped suddenly from $35.52 \%$ to $32.79 \% \quad(\Delta S=2.73 \%$ over a distance about $2.4 \mathrm{~km}$ (Fig. 3), which showed a salinity gradient of $\sim 0.11 \% \% / \mathrm{hm}$. The temperature increase across this boundary is about $0.4^{\circ} \mathrm{C}\left(20.2^{\circ} \mathrm{C}\right.$ to $\left.20.6^{\circ} \mathrm{C}\right)$.

After the crossing of this boundary $\left(S F_{2}\right)$ a salinity minimum of $-32.4 \%$ was found near I lha das Palmas (Fig. 1, Point C). In this region the temperature was almost constant $\left(\mathrm{T} \sim 20.9^{\circ} \mathrm{C}\right)$.

Along the track CDE (Fig. 3) both temperature and salinity showed fluctuations ranging between $\sim 0.05^{\circ} \mathrm{C}$ to $0.5^{\circ} \mathrm{C}$ and $\sim 0.02 \%$ to $\sim 0.5 \%$, respectively. The salinity increased up to $34.5 \%$, and after this maximum the salinity decreased to $33.85 \%$ at the end of this section. Salinity fluctuations along this track may be due to the temperature compensation of the salinity measurements circuit. 
The surface water along the region where the water from Baía de Sepetiba interchanges with that from Baía da Ilha Grande located in the north of Ilha Grande, showed a pronounced increase in salinity values about $1.9 \%$ $(\sim 33.8 \%$ to $35.7 \%$ oo $)$, which is associated to a slight temperature increase from $-21.2^{\circ} \mathrm{C}$ to $21.7^{\circ} \mathrm{C}$ (Fig. 4).
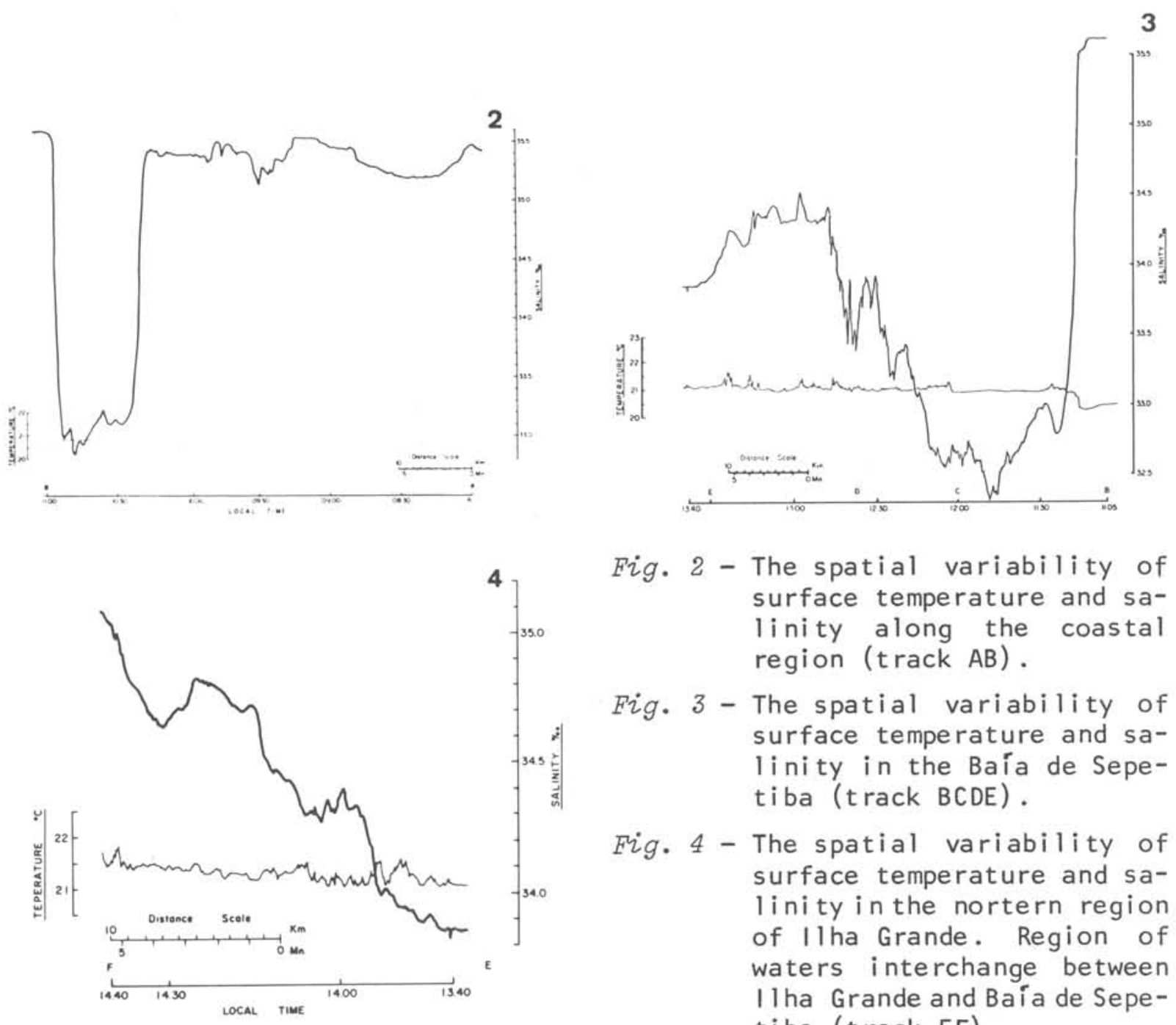

Fig. 2 - The spatial variability of surface temperature and salinity along the coastal region (track $A B$ ).

Fig. 3 - The spatial variability of surface temperature and salinity in the Baía de Sepetiba (track $B C D E$ ).

Fig. 4 - The spatial variability of surface temperature and salinity in the nortern region of Ilha Grande. Region of waters interchange between I Tha Grande and Baía de Sepetiba (track EF).

The thermal and saline structures on the surface water in Baía da Ilha Grande are shown in Figures 5-6 (track FGHIJK). The general trend of saiinity and temperature indicates that the surface water in this Bay is more saline and slightly warmer than in the eastern region of the I1ha Grande. Studies by Tommasi et al. $(1972 a, b)$, based on discrete measurements 
in a dense network of hydrographic stations, demonstrated the same characteristics of the salinity differences of the bottom waters between Baía da Ilha Grande and Baía de Sepetiba. The coastal runoff into the Baía de Sepetiba may be the main reason to explain this great difference of salt content in these waters.

In the inner region of the Baía da Ilha Grande, temperature structure presented minor fluctuations, showing slightly higher values $(\mathrm{T} \sim 21.2$ to $22.0^{\circ} \mathrm{C}$ ), than those obtained in the south entrance of this Bay, $\mathrm{T} \sim 20.8$ to $21.3^{\circ} \mathrm{C}$ ) (Figs $5-6$ ).

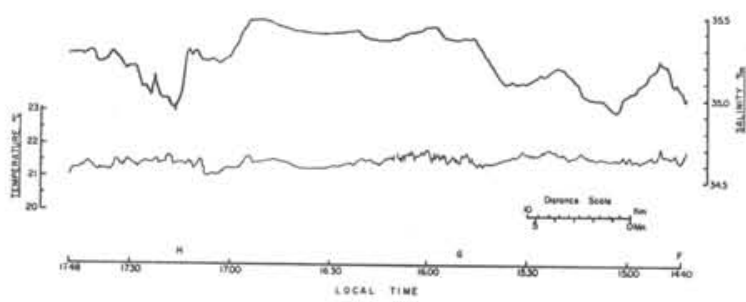

Fig. 5 - The spatial variability of surface temperature and salinity in the Baía da Ilha Grande (track FGH).

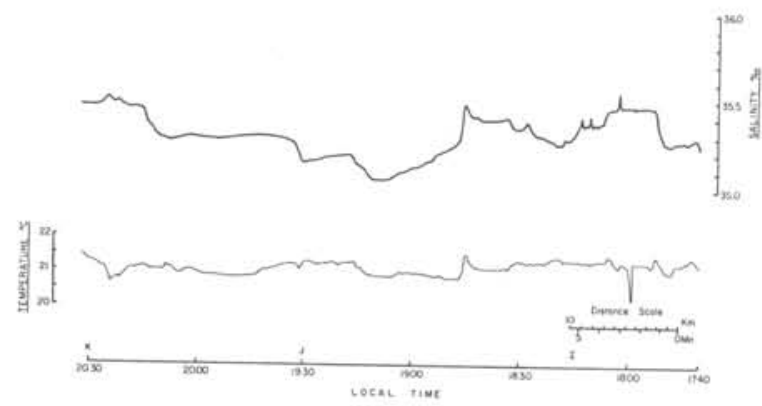

Fig. 6 - The spatial variability of surface temperature and salinity in the Baía da Ilha Grande (track HIJK).

\section{CONCLUSIONS}

Based on the data presented, the following conclusions may be reached:

1. The less saline outflow between Ponta de Castelhanos and Ponta Grossa da Marambáia produces a well delimited visible saline front.

2. The surface waters of the Baía da Ilha Grande are more saline and slightly warmer than those of the Baía de Sepetiba. Our results and former investigations in this region support the hypothesis that the main source of this less saline waters is the inner region of the Baía de Sepetiba.

3. The salinity gradients across the boundaries, indicating the transition between the more saline coastal waters and the less saline waters, are 
stronger in the boundary located SE of the Ponta Grossa da Marambáia. The breadth of the less saline waters was about $9.4 \mathrm{~km}$.

4. The offshore extent of this coastal influence, its driving forces and prediction, the induced circulation in the inner region producing a water exchange between Baía da Ilha Grande and Baía de Sepetiba, require further experimental studies.

\section{RESUMO}

Registros contínuos da temperatura e da salinidade, em função de distâncias horizontais, foram obtidos para as águas de superfície existentes ao redor da I1ha Grande, em 21 de junho de 1975. Foi detectado um fluxo de água com baixa salinidade $(\mathrm{S} \sim 33,10 \%$ \% $)$ e temperatura ligeiramente maior do que a das águas adjacentes, na região entre a Ponta de Castelhanos e a Ponta Grossa da Marambäia. A interação entre este fluxo e as águas costeiras mais salinas $\left(\mathrm{S} \sim 35,4\right.$ a $35,6^{\circ} \%$ o $)$ se apresentou de forma visível, como uma frente salina.

Os valores de salinidade, registrados à leste da Ilha Grande sugerem, que a origem dessa água de baixa salinidade é a descarga fluvial na Baía de Sepetiba.

\section{ACKNOWLEDGEMENTS}

The authors wish to express their thanks to all members of the Instituto Oceanográfico da Universidade de São Paulo, who made possible this publication.

We are also grateful to the Instituto de Pesquisas Espaciais (INPE), which provided for the electronic equipment for the quasi-synoptic measurements, as well as to the Multinational Project on Marine Sciences, Project BR-19-CA-A (OEA), which provided for the salinity data checking equipment.

We would also like to extend our gratitude to the Fundação de Amparo à Pesquisa do Estado de São Paulo (FAPESP) for the fellowship grants awarded (contracts 74/0439 and 75/0412), and to Mrs Sumiko N. Ikeda for the final English form of this paper. 


\section{REFERENCES}

AMOS, A. F.; LANGSETH Jr., M. \& MARKL, R. G. 1972. Visible oceanic saline fronts. In: Gordon, A. L., ed.- Studies in physical oceanography. New York, Gordon \& Breach, vol. 1, :49-62.

CROMWELL, T. \& REID, J. L. 1956. A study of oceanic fronts. Tellus, $8 .(1): 94-101$.

IKEDA, Y. 1971. Relatōrio sobre a instalação do termo-salinógrafo e seu funcionamento no N/Oc. "Prof. W. Besnard". (unpublished manuscript).

LAEVASTU, T. 1973. Coastal sea-air interactions and the extent of coastal influence. Progress Report no 2. Tech. Note Envir. Pred. Res. Fac., (8) : 1-32.

PINGREE, R. D.; FORSTER, G. R. \& MORRISON, G. K. 1974. Turbulent convergent tidal fronts. J. mar. biol. Ass. U.K., 54:469-479.

TOMMASI, L. R.; MARINI, A. C. \& ROSA, C. F. A. 1972a. Briozoārios lunulitiformes da região da Ilha Grande (RJ). Bolm Inst. oceanogr., S Paulo, 21:137-147.

VALENTE, M. T. M. \& ACEDO, R.

1972b. Cephalochordata da região da I1ha Grande (RJ). Bolm Inst. oceanogr., S Paulo, 21:149-162.

(Received December 10, 1975) 